\title{
Therapy-induced Deletion in 11q23 Leading to Fusion of KMT2A With ARHGEF12 and Development of B Lineage Acute Lymphoplastic Leukemia in a Child Treated for Acute Myeloid Leukemia Caused by $\mathrm{t}(9 ; 11)(\mathrm{p} 21 ; \mathrm{q} 23) / K M T 2 A-M L L T 3$
}

\author{
IOANNIS PANAGOPOULOS ${ }^{1}$, KRISTIN ANDERSEN $^{1}$, MARTINE EILERT-OLSEN ${ }^{1}$, \\ BERNWARD ZELLER $^{2}$, MONICA CHENG MUNTHE-KAAS ${ }^{2}$, JOCHEN BUECHNER ${ }^{2}$, \\ LIV T.N. OSNES ${ }^{3}$, FRANCESCA MICCI ${ }^{1}$ and SVERRE HEIM ${ }^{1,4}$ \\ ${ }^{1}$ Section for Cancer Cytogenetics, Institute for Cancer Genetics and Informatics, \\ The Norwegian Radium Hospital, Oslo University Hospital, Oslo, Norway; \\ ${ }^{2}$ Department of Pediatric Hematology and Oncology, Oslo University Hospital, Rikshospitalet, Oslo, Norway; \\ ${ }^{3}$ Department of Immunology, Oslo University Hospital, Rikshospitalet, Oslo, Norway; \\ ${ }^{4}$ Institute of Clinical Medicine, Faculty of Medicine, University of Oslo, Oslo, Norway
}

\begin{abstract}
Background/Aim: Fusion of histone-lysine Nmethyltransferase $2 A$ gene (KMT2A) with the Rho guanine nucleotide exchange factor 12 gene (ARHGEF12), both located in 11q23, was reported in some leukemic patients. We report a KMT2A-ARHGEF 12 fusion occurring during treatment of a pediatric acute myeloid leukemia (AML) with topoisomerase II inhibitors leading to a secondary acute lymphoblastic leukemia $(A L L)$. Materials and Methods: Multiple genetic analyses were performed on bone marrow cells of a girl initially diagnosed with AML. Results: At the time of diagnosis with AML, the $t(9 ; 11)(p 21 ; q 23) / K M T 2 A-M L L T 3$ genetic abnormality was found. After chemotherapy resulting in AML clinical remission, a $2 \mathrm{Mb}$ deletion in 11 q23 was found generating a KMT2AARHGEF12 fusion gene. When the patient later developed $B$ lineage ALL, a t(14;19)(q32;q13), loss of one chromosome 9, and KMT2A-ARHGEF12 were detected. Conclusion: The patient sequentially developed $A M L$ and $A L L$ with three leukemia-specific genomic abnormalities in her bone marrow cells, two of which were KMT2A-rearrangements.
\end{abstract}

This article is freely accessible online.

Correspondence to: Ioannis Panagopoulos, Section for Cancer Cytogenetics, Institute for Cancer Genetics and Informatics, The Norwegian Radium Hospital, Oslo University Hospital, P.O. Box 4953 Nydalen, NO-0424 Oslo, Norway. Tel: +47 22934424, email: ioannis.panagopoulos@rr-research.no

Key Words: Pediatric leukemia, acute myeloid leukemia, acute lymphoblastic leukemia, chemotherapy, fusion gene, $K M T 2 A$, ARHGEF12, KMT2A-ARHGEF12, KMT2A-MLLT3.
The histone-lysine $\mathrm{N}$-methyltransferase 2A (KMT2A, also known as $M L L)$ gene in 11q23 $(1,2)$ may fuse with more than 100 different partners in acute lymphoblastic leukemia (ALL), acute myeloid leukemia (AML), chronic myeloid leukemia, myelodysplastic syndromes, lymphomas, and solid tumors (3). Some of the resulting chimeras are common, such as the fusions with the AF4/FMR2 family member $1(A F F 1)$ and MLLT3 super elongation complex subunit (MLLT3) genes generated by $\mathrm{t}(4 ; 11)(\mathrm{q} 21 ; \mathrm{q} 23)$ in ALL $(K M T 2 A-A F F 1)$ and $\mathrm{t}(9 ; 11)(\mathrm{p} 21 ; \mathrm{q} 23)$ in AML (KMT2A-MLLT3), while others have only been reported in few or single cases $(4,5)$. The prognostic impact of the frequent $K M T 2 A$ fusions is well known $(6,7)$; however, knowledge about the clinical consequences of the infrequent chimeras is inadequate. For this reason, not just because of biological curiosity, the reporting of cases involving uncommon $K M T 2 A$ fusions is important as recently exemplified by the description of rare KMT2A-ELL fusion transcripts in pediatric AML associated with myeloid sarcomas (8-11).

We herein report the first pediatric leukemia, and the sixth case overall, in which fusion of KMT2A with the Rho guanine nucleotide exchange factor 12 (ARHGEF 12) gene was detected.

\section{Materials and Methods}

Ethics statement. The study was approved by the regional ethics committee (Regional komité for medisinsk forskningsetikk Sør-Øst, Norge, http://helseforskning.etikkom.no), and written informed consent was obtained from the patient's parents. The Ethics Committee's approval included a review of the consent procedure. All patient information has been anonymized.

Case report. The patient was a girl diagnosed with AML at an age of 9.5 years (Table I, Sample S0), after a period of three months 
Table I. G-banding, fluorescence in situ hybridization (FISH) and molecular genetic results of the patient.

\begin{tabular}{|c|c|c|c|c|c|}
\hline Sample & $\begin{array}{l}\text { Days from } \\
\text { AML-diagnosis }\end{array}$ & Karyotype & $\begin{array}{l}\text { Nuclear in situ } \\
\text { hybridization (nuc ish) } \\
\text { based on } K M T 2 A \\
\text { break-apart probe }\end{array}$ & $\begin{array}{c}\text { Aberrant } \\
\text { nuclei }(\%)\end{array}$ & $\begin{array}{l}\text { Additional } \\
\text { experiments }\end{array}$ \\
\hline So & 0 & $\begin{array}{l}46, X X, t(9 ; 11) \\
(\mathrm{p} 21 ; \mathrm{q} 23)[9] / \\
46, X X[2]\end{array}$ & $\begin{array}{c}\text { nucish (KMT2Ax2)(5`KMT2A sep } \\
\text { 3`KMT2Ax1)[195/204] }\end{array}$ & $96 \%$ & $\begin{array}{l}\text { FISH with a KMT2A-MLLT3 dual } \\
\text { fusion probe: Fusion in metaphase spreads } \\
\text { and in } 184 \text { out of } 190(97 \%) \text { nuclei } \\
\text { Neither RT-PCR nor genomic PCR amplified } \\
\text { KMT2A-ARHGEF12 fusion fragments }\end{array}$ \\
\hline S1 & $\begin{array}{c}300 \\
\text { (9 months and } \\
24 \text { days) }\end{array}$ & Fail & $\begin{array}{c}\text { nuc ish }\left(5^{\prime} \mathrm{KMT} 2 \mathrm{Ax} 2,3^{\prime} \mathrm{KMT} 2 \mathrm{Ax} 1\right) \\
\left(5^{\prime} \mathrm{KMT} 2 \mathrm{~A} \text { con } 3^{\prime} \mathrm{KMT} 2 \mathrm{Ax} 1\right)[160 / 200]\end{array}$ & $80 \%$ & Not done \\
\hline S2 & $\begin{array}{c}328 \\
\text { (10 months and } \\
23 \text { days) }\end{array}$ & $46, X X$ & $\begin{array}{c}\text { nuc ish }\left(5^{\prime} \mathrm{KMT} 2 \mathrm{Ax} 2,3^{\prime} \mathrm{KMT} 2 \mathrm{Ax} 1\right) \\
\left(5^{\prime} \mathrm{KMT} 2 \mathrm{~A} \text { con } 3^{\prime} \mathrm{KMT} 2 \mathrm{Ax} 1\right)[181 / 204]\end{array}$ & $89 \%$ & Not done \\
\hline S3 & $\begin{array}{c}389 \\
\text { (1 year and } \\
23 \text { days })\end{array}$ & $46, X X$ & $\begin{array}{c}\text { nuc ish }\left(5^{\prime} \mathrm{KMT} 2 \mathrm{Ax} 2,3^{\prime} \mathrm{KMT} 2 \mathrm{Ax} 1\right) \\
\left(5^{\prime} \mathrm{KMT} 2 \mathrm{~A} \text { con } 3^{\prime} \mathrm{KMT} 2 \mathrm{Ax} 1\right)[184 / 200]\end{array}$ & $92 \%$ & $\begin{array}{l}\text { RNA sequencing: Detection of a } \\
K M T 2 A-A R H G E F 12 \text { fusion transcript } \\
\text { RT-PCR/Sanger sequencing: } \\
\text { Confirmation of the presence of the } \\
\text { KMT2A-ARHGEF12 fusion transcript }\end{array}$ \\
\hline S4 & $\begin{array}{l}466 \\
\text { (1 year, } 3 \text { months, } \\
\text { and } 8 \text { days })\end{array}$ & $46, \mathrm{XX}$ & $\begin{array}{c}\text { nuc ish }\left(5^{\prime} \mathrm{KMT} 2 \mathrm{Ax} 2,3^{\prime} \mathrm{KMT} 2 \mathrm{Ax} 1\right) \\
\left(5^{\prime} \mathrm{KMT} 2 \mathrm{~A} \text { con } 3^{\prime} \mathrm{KMT} 2 \mathrm{Ax} 1\right)[199 / 219]\end{array}$ & $91 \%$ & Not done \\
\hline S5 & $\begin{array}{c}571 \\
\text { (1 year, } 6 \text { months, } \\
\text { and } 21 \text { days })\end{array}$ & $46, \mathrm{XX}$ & $\begin{array}{c}\text { nuc ish }\left(5^{\prime} \mathrm{KMT} 2 \mathrm{Ax} 2,3^{\prime} \mathrm{KMT} 2 \mathrm{Ax} 1\right) \\
\left(5^{\prime} \mathrm{KMT} 2 \mathrm{~A} \text { con } 3^{\prime} \mathrm{KMT} 2 \mathrm{Ax} 1\right)[164 / 219]\end{array}$ & $89 \%$ & Not done \\
\hline S6 & $\begin{array}{c}718 \\
\text { (1 year, } 11 \text { months, } \\
\text { and } 17 \text { days })\end{array}$ & $46, \mathrm{XX}$ & $\begin{array}{c}\text { nuc ish }\left(5^{\prime} \mathrm{KMT} 2 \mathrm{Ax} 2,3^{\prime} \mathrm{KMT} 2 \mathrm{Ax} 1\right) \\
\left(5^{\prime} \mathrm{KMT} 2 \mathrm{~A} \text { con } 3^{\prime} \mathrm{KMT} 2 \mathrm{Ax} 1\right)[158 / 200]\end{array}$ & $79 \%$ & $\begin{array}{l}\text { FISH with a } K M T 2 A-M L L T 3 \\
\text { dual fusion: No fusion in } 200 \text { nuclei }\end{array}$ \\
\hline S7 & $\begin{array}{l}914 \\
\text { (2 years, } 5 \text { months, } \\
\text { and } 30 \text { days })\end{array}$ & $46, \mathrm{XX}$ & Not done & & $\begin{array}{l}\text { FISH with a } K M T 2 A-M L L T 3 \text { dual } \\
\text { fusion probe: No fusion in } 200 \text { nuclei }\end{array}$ \\
\hline S8 & $\begin{array}{l}1,198 \\
\text { (3 years, } 3 \text { months, } \\
\text { and } 10 \text { days), at } \\
\text { clinical diagnosis } \\
\text { of B lineage ALL }\end{array}$ & $\begin{array}{c}45, \mathrm{XX},-9 \\
\mathrm{t}(14 ; 19) \\
(\mathrm{q} 32 ; \mathrm{q} 13)[8] / \\
46, \mathrm{XX}[3]\end{array}$ & $\begin{array}{c}\text { nuc ish }\left(5^{\prime} \mathrm{KMT} 2 \mathrm{Ax} 2,3^{\prime} \mathrm{KMT} 2 \mathrm{Ax} 1\right) \\
\left(5^{\prime} \mathrm{KMT} 2 \mathrm{~A} \text { con } 3^{\prime} \mathrm{KMT} 2 \mathrm{Ax} 1\right) \\
{[194 / 200]}\end{array}$ & $97 \%$ & $\begin{array}{c}\text { Genomic PCR/Sanger sequencing: } \\
\text { Detection of the genomic breakpoint/ } \\
\text { junction of } K M T 2 A-A R H G E F 12 \text { fusion gene } \\
\text { FISH with a } K M T 2 A-M L L T 3 \text { dual } \\
\text { fusion probe: No fusion in } 200 \text { nuclei } \\
\text { FISH with } I G H \text { break-apart probe: } \\
\text { Split of } I G H \text { probe in } 195 \text { out } \\
\text { of } 211(92 \%) \text { nuclei }\end{array}$ \\
\hline S9 & $\begin{array}{l}1,294 \\
\text { (3 years, } 6 \text { months, } \\
\text { and } 14 \text { days) }\end{array}$ & Fail & $\begin{array}{l}\text { nuc ish }\left(5^{\prime} \mathrm{KMT} 2 \mathrm{Ax} 2,3^{\prime} \mathrm{KMT} 2 \mathrm{Ax} 1\right) \\
\left(5^{\prime} \mathrm{KMT} 2 \mathrm{~A} \text { con } 3^{\prime} \mathrm{KMT} 2 \mathrm{Ax} 1\right)[17 / 200]\end{array}$ & $8.5 \%$ & $\begin{array}{l}\text { FISH with IGH break-apart probe: } \\
\text { No split of IGH in } 200 \text { nuclei }\end{array}$ \\
\hline S10 & $\begin{array}{l}1,539 \\
\text { (4 years, } 2 \text { months, } \\
\text { and } 17 \text { days })\end{array}$ & $46, \mathrm{XX}$ & $\begin{array}{c}\text { nuc ish }\left(5^{\prime} \mathrm{KMT} 2 \mathrm{Ax} 2,3^{\prime} \mathrm{KMT} 2 \mathrm{Ax} 1\right) \\
\left(5^{\prime} \mathrm{KMT} 2 \mathrm{~A} \text { con } 3^{\prime} \mathrm{KMT} 2 \mathrm{Ax} 1\right)[164 / 203]\end{array}$ & $81 \%$ & $\begin{array}{c}\text { Genomic PCR/Sanger sequencing: } \\
\text { Detection of the genomic breakpoint/ } \\
\text { junction of } K M T 2 A-A R H G E F 12 \text { fusion gene } \\
\text { aCGH detected a } 2 \mathrm{Mbp} \text { deletion between } \\
\text { KMT2A and ARHGEF12 genes }\end{array}$ \\
\hline S11-A & $\begin{array}{c}1,686 \mathrm{~A} \\
\text { (4 years, } 7 \text { months, } \\
\text { and } 11 \text { days })\end{array}$ & $46, \mathrm{XX}$ & $\begin{array}{l}\text { nuc ish }\left(5^{\prime} \mathrm{KMT} 2 \mathrm{Ax} 2,3^{\prime} \mathrm{KMT} 2 \mathrm{Ax} 1\right) \\
\left(5^{\prime} \mathrm{KMT} 2 \mathrm{~A} \text { con } 3^{\prime} \mathrm{KMT} 2 \mathrm{Ax} 1\right)[87 / 212]\end{array}$ & $41 \%$ & Not done \\
\hline S11-B & $\begin{array}{c}1,686 \mathrm{~B} \\
\text { (4 years, } 7 \text { months, } \\
\text { and } 11 \text { days })\end{array}$ & Not done & $\begin{array}{l}\text { nuc ish }\left(5^{\prime} \mathrm{KMT} 2 \mathrm{Ax} 2,3^{\prime} \mathrm{KMT} 2 \mathrm{Ax} 1\right) \\
\left(5^{\prime} \mathrm{KMT} 2 \mathrm{~A} \text { con } 3^{\prime} \mathrm{KMT} 2 \mathrm{Ax} 1\right)[85 / 110]\end{array}$ & $77 \%$ & Not done \\
\hline S11-C & $\begin{array}{c}1,686 \mathrm{C} \\
\text { (4 years, } 7 \text { months, } \\
\text { and } 11 \text { days) }\end{array}$ & Not done & $\begin{array}{c}\text { nuc ish }\left(5^{\prime} \mathrm{KMT} 2 \mathrm{Ax} 2,3^{\prime} \mathrm{KMT} 2 \mathrm{Ax} 1\right) \\
\left(5^{\prime} \mathrm{KMT} 2 \mathrm{~A} \text { con } 3^{\prime} \mathrm{KMT} 2 \mathrm{Ax} 1\right)[115 / 335]\end{array}$ & $34 \%$ & Not done \\
\hline
\end{tabular}


Table I. Continued

\begin{tabular}{|c|c|c|c|c|c|}
\hline Sample & $\begin{array}{l}\text { Days from } \\
\text { AML-diagnosis }\end{array}$ & Karyotype & $\begin{array}{c}\text { Nuclear in situ } \\
\text { hybridization (nuc ish) } \\
\text { based on } K M T 2 A \\
\text { break-apart probe }\end{array}$ & $\begin{array}{c}\text { Aberrant } \\
\text { nuclei }(\%)\end{array}$ & $\begin{array}{l}\text { Additional } \\
\text { experiments }\end{array}$ \\
\hline $\mathrm{S} 12$ & $\begin{array}{c}1,945 \\
\text { (5 years, } 3 \text { months, } \\
26 \text { days), } 3 \text { months } \\
\text { after stem cell } \\
\text { transplantation }\end{array}$ & Not done & $\begin{array}{c}\text { nuc ish }\left(5^{`} \mathrm{KMT} 2 \mathrm{~A}, 3^{\prime} \mathrm{KMT} 2 \mathrm{~A}\right) \mathrm{x} \\
2\left(5^{\prime} \mathrm{KMT} 2 \mathrm{~A} \text { con } 3^{\prime} \mathrm{KMT} 2 \mathrm{Ax} 2\right)[200]\end{array}$ & $100 \%$ & Not done \\
\hline
\end{tabular}

Clinical diagnosis of acute myeloid leukemia (AML) at time point (sample) S0, diagnosis of B lineage acute lymphoblastic leukemia (ALL) at time point S8. Sample 11 (S11-A, S11-B, and S-11C) represents the last bone marrow before stem cell transplantation. Sample 12 represents bone marrow 3 months after stem cell transplantation. RT-PCR: reverse transcription-polymerase chain reaction. aCGH: array comparative genomic hybridization.A: Bone marrow. B: CD34+/CD117+ cells. C: Negative fraction.

with fatigue, pallor, headache, and dizziness. There was no history of hematologic diseases, leukemia or frequent cancers in the family. At admittance, she was in good shape. Physical examination was normal except for pallor. Spleen and liver size were normal. Her blood tests were abnormal with hemoglobin $5.8 \mathrm{~g} / \mathrm{dl}$, platelet count $95 \times 10^{9} / 1$, white blood cell count $4.9 \times 10^{9} / 1$, and neutrophils $0.1 \times 10^{9} / 1$. Bone marrow investigation revealed findings indicative of acute myelomonocytic leukemia (AML M4), and cytogenetic analysis showed a $\mathrm{t}(9 ; 11)(\mathrm{p} 21 ; \mathrm{q} 23)$ chromosome translocation (Table I, sample S0, see below).

The girl was treated according to the NOPHO-DBH 2012 protocol (12) where she was classified as a standard risk patient. She received five chemotherapy courses including the drugs liposomal daunorubicin, mitoxantrone, etoposide, cytarabine, and fludarabine. Following completion of therapy, she entered a prolonged phase with moderate pancytopenia. During this period which lasted two years and three months, repeated bone marrow examinations were performed (Table I, samples S1-S7). They revealed hematological remission and a normal karyotype but with a persisting KMT2A rearrangement, however one that was different from the original KMT2A-MLLT3 (Table I, samples S1-S7, see below). Flow cytometry showed a small persisting CD34+, CD38+ cell population with aberrant phenotype (reduced HLA-DR, CD33 weak/negative, CD11a weak, $\mathrm{CD} 117$ heterogenous), in a proportion decreasing from $1.5 \%$ to $0.05 \%$, in addition to the phenotypically normal CD34+ CD38+ myeloid precursors, over eight months. The girl was always in good general health and lived a completely normal life. Following normalization of her peripheral blood values, no more bone marrow examinations were performed until she, two years and nine months after start of the last AML chemotherapy course (or three years and three months after the initial diagnosis of AML), again developed pancytopenia. She was now diagnosed with ALL (Table I, S8). The bone marrow contained $90 \%$ blasts of pre-B phenotype, whereas cytogenetic analysis revealed a $\mathrm{t}(14 ; 19)(\mathrm{q} 32 ; \mathrm{q} 13)$ chromosome translocation together with loss of one chromosome 9 (Table I, sample S8, see below). Treatment according to the NOPHO-ALL 2008 protocol (13) was begun but, due to increased toxicity, had to be modified. Bone marrow controls during therapy confirmed a good and early treatment response with swift reduction of the lymphoblasts. However, the same small population of abnormal CD34+, CD38+ cells detected shortly after discontinuation of the primary AML treatment and persisting ever since, was still detectable. It was therefore decided to give her one dose of Daratumomab (a CD38antibody) $16 \mathrm{mg} / \mathrm{kg}$ with the aim of eradicating the abnormal clone before stem cell transplantation. After the one dose of Daratumomab CD38 was not detected on any CD34+ cells, using the standard monoclonal anti-CD38. However, using a multiepitope anti-CD38 the antigen could still be detected, indicating down-regulation of the epitope detected by the monoclonal antibody. Other markers demonstrated that the abnormal population was still present in the first controls after Daratumomab. The first bone marrow negative for CD34+ cells was confirmed 11 weeks after initiation of Daratumomab treatment, i.e., more than four years after the clone was first detected. Six weeks after the first negative bone marrow, allogeneic stem cell transplantation was performed with a human leukocyte antigen (HLA) - matched, unrelated donor after standard ALL-conditioning regimen consisting of total body irradiation (TBI) and etoposide. The patient is presently in complete remission, three months after stem cell transplantation. The current bone marrow assessment did not detect abnormal CD34+CD38+ cells or rearrangement of the KMT2A gene (see below).

G-banding and fluorescence in situ hybridization (FISH) analyses. Bone marrow cells were short-term cultured, G-banded, and analyzed cytogenetically as previously described (14).

FISH analyses of bone marrow interphase nuclei and metaphase spreads were performed with the Cytocell KMT2A (MLL) and IGH break-apart probes, as well as with KMT2A-MLLT3 translocation dual fusion probes (Cytocell, Oxford Gene Technology, Begbroke, Oxfordshire, UK). Fluorescent signals were captured and analyzed using the CytoVision system (Leica Biosystems, Newcastle, UK).

DNA and RNA isolation and complementary DNA (cDNA) synthesis. Genomic DNA was extracted from the patient's bone marrow samples at diagnosis as well as 1,198 and 1,539 days after the diagnosis (Table I, samples S0, S8, and S10) using the Maxwell 16 Instrument System and the Maxwell 16 Cell DNA Purification Kit (Promega, Madison, WI, USA). Total RNA was extracted from the patient's bone marrow at diagnosis and after 389 days (Table I, samples S0, and S3) using the miRNeasy Mini Kit (Qiagen, Hilden, Germany) and the QiaCube automated purification system according to the manufacturer's instructions (Qiagen). The concentration and purity of DNA and RNA 
Table II. Primers used for PCR amplification and Sanger sequencing analyses. The M13 forward and reverse primer sequences are in bold and italics.

\begin{tabular}{|c|c|c|c|c|}
\hline Name & Sequence $\left(5^{\prime}->3^{\prime}\right)$ & Position & $\begin{array}{l}\text { Reference } \\
\text { sequence }\end{array}$ & Gene \\
\hline M13For-MLL-4010F1 & $\boldsymbol{T} \boldsymbol{G} \boldsymbol{T} \boldsymbol{A} \boldsymbol{A} \boldsymbol{A} \boldsymbol{A} \boldsymbol{C} \boldsymbol{G} \boldsymbol{A} \boldsymbol{C} \boldsymbol{G} \boldsymbol{C} \boldsymbol{C} \boldsymbol{A} \boldsymbol{G} \boldsymbol{T}$ AAAGCAGCCТCСАССАССАGАAТ & 4010-4032 & NM_005933.3 & KMT2A \\
\hline M13For-MLL-4115F1 & TGTAAAACGACGGCCAGTACCACCTCCGGTCAATAAGCAGG & $4115-4137$ & NM_005933.3 & $K M T 2 A$ \\
\hline M13Rev-ARHGEF12-1515R1 & 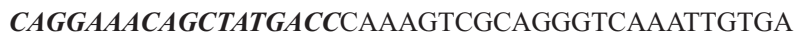 & $1537-1515$ & NM_015313.2 & ARHGEF12 \\
\hline M13Rev-ARHGEF12-1579R1 & 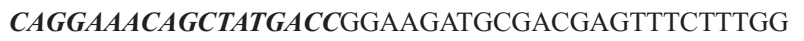 & $1579-1602$ & NM_015313.2 & ARHGEF12 \\
\hline MLL-4116-F1 & CCACCTCCGGTCAATAAGCAGGAGAA & $4116-4141$ & NM_005933.3 & KMT2A \\
\hline MLL-4202-F1 & TCCAGCAGATGGAGTCCACAGGATCA & $4202-4227$ & NM_005933.3 & KMT2A \\
\hline ARHGEF12-1437-R1 & TTCAATGCTCTGGAAACAGCTGCACTG & $1463-1437$ & NM_015313.2 & ARHGEF 12 \\
\hline ARHGEF12-1502-R1 & GCAGGGTCAAATTGTGAAACTACATGGTGT & $1531-1502$ & NM_015313.2 & ARHGEF 12 \\
\hline
\end{tabular}

were measured with the QIAxpert microfluidic UV/VIS spectrophotometer (Qiagen). In addition, the Agilent 2100 bioanalyzer and the RNA Integrity Number (RIN) were used to assess the RNA quality (15). RIN of RNA was 6.6. cDNA was synthesized from one $\mu \mathrm{g}$ of total RNA using the iScript Advanced cDNA Synthesis Kit for RT-qPCR according to the manufacturer's instructions (Bio-Rad, Hercules, CA, USA). The quality of the cDNA synthesis was assessed by amplification of a cDNA fragment of the ABL protooncogene 1, non-receptor tyrosine kinase $(A B L 1)$ gene using the primer combination ABL1-91F1/ABL1-404R1 (16).

RNA sequencing. High-throughput paired-end RNA-sequencing was performed at the Genomics Core Facility, Norwegian Radium Hospital, Oslo University Hospital (http://genomics.no/oslo/). For library preparation from total RNA, the Illumina TruSeq RNA Access Library Prep kit was used according to Illumina's protocol (Illumina, San Diego, CA, USA). Sequencing was performed on a NextSeq 550 System (Illumina) and 76 million reads were generated. The FASTQC software was used for quality control of the raw sequence data (https://www.bioinformatics.babraham.ac.uk/projects/fastqc/). The software FusionCatcher was used to find fusion transcripts $(17,18)$.

PCR analyses. The primers used for PCR amplification and Sanger sequencing are listed in Table II. For reverse transcriptionpolymerase chain reaction (RT-PCR) and cycle Sanger sequencing, the BigDye Direct Cycle Sequencing Kit was used (ThermoFisher Scientific, Waltham, MA, USA) according to the company's recommendations. As template, cDNA corresponding to $20 \mathrm{ng}$ total RNA was used. The primer combinations were M13For-MLL4010F1/M13Rev-ARHGEF12-1579R1 and M13For-MLL-4115F1/ M13Rev-ARHGEF12-1515R1. For the detection of possible KMT2A-ARHGEF12 chimeric cDNA fragments at initial diagnosis, the primer combination MLL-4116-F1/ARHGEF12-1502-R1 was used as described below.

Genomic PCR amplifications were performed in $25 \mu$ reaction volume which contained 12.5 $\mu$ Premix Ex Taq ${ }^{\mathrm{TM}}$ DNA Polymerase Hot Start Version (Takara Bio Europe/SAS, Saint-Germain-en-Laye, France), $100 \mathrm{ng}$ of genomic DNA, and $0.4 \mu \mathrm{M}$ of each of the forward and reverse primers. The primer combinations were MLL4116-F1/ARHGEF12-1502-R1 and MLL-4202-F1/ARHGEF121437-R1. The PCR cycling conditions were an initial denaturation step at $94^{\circ} \mathrm{C}$ for $30 \mathrm{sec}$ followed by 35 cycles of $7 \mathrm{sec}$ at $98^{\circ} \mathrm{C}$ and $2 \mathrm{~min}$ at $68^{\circ} \mathrm{C}$, and a final extension for $5 \mathrm{~min}$ at $68^{\circ} \mathrm{C}$. Three $\mu \mathrm{l}$ of the PCR products were stained with GelRed (Biotium, Fremont, CA, USA), analyzed by electrophoresis through $1 \%$ agarose gel, and photographed. DNA gel electrophoresis was performed using lithium borate buffer (19). The remaining PCR products were purified using the MinElute PCR Purification Kit (Qiagen) and direct sequenced using the dideoxy procedure with the BigDye terminator v1.1 cycle sequencing kit following the company's recommendations (ThermoFisher Scientific).

Sequence analyses were performed on the Applied Biosystems SeqStudio Genetic Analyzer system (ThermoFisher Scientific). The basic local alignment search tool (BLAST) software (https://blast.ncbi.nlm.nih.gov/Blast.cgi) was used for computer analysis of sequence data (20). The BLAT alignment tool and the human genome browser at UCSC were also used to map the sequences on the Human GRCh37/hg19 assembly $(21,22)$.

Array comparative genomic hybridization (aCGH) analysis. aCGH was performed using the CytoSure array products (Oxford Gene Technology, Begbroke, Oxfordshire, UK) following the company's protocols. Thus, the CytoSure Genomic DNA Labelling Kit was used for the labelling of $1 \mu \mathrm{g}$ of patient's and reference DNAs and the CytoSure Cancer +SNP array for hybridization. The patient's DNA was that isolated from a sample drawn 1,539 days after the initial diagnosis of AML (Table I, S10). The reference DNA was Promega's human genomic female DNA (Promega, Madison, WI, USA). The slides were scanned by an Agilent scanner using Agilent Feature Extraction Software (version 10.7.3.1). Data were analysed using the CytoSure Interpret analysis software (version 4.9.40). Annotations are based on human genome build 19.

\section{Results}

G-banding analyses. The data from G-banding and FISH analyses are summarized in Table I. The G-banding analysis of bone marrow cells at diagnosis yielded the karyotype 46,XX,t(9;11)(p21;q23)[9]/46,XX[2] (Figure 1A). Subsequently, bone marrow G-banding analyses always showed a normal 46,XX karyotype except for the sample obtained 1,198 days after diagnosis. At that point, the karyotype had become 45,XX,-9, t(14;19)(q32;q13)[8]/ 46,XX[3] and the patient had developed B lineage ALL (Table I, sample S8) (Figure 1B). 

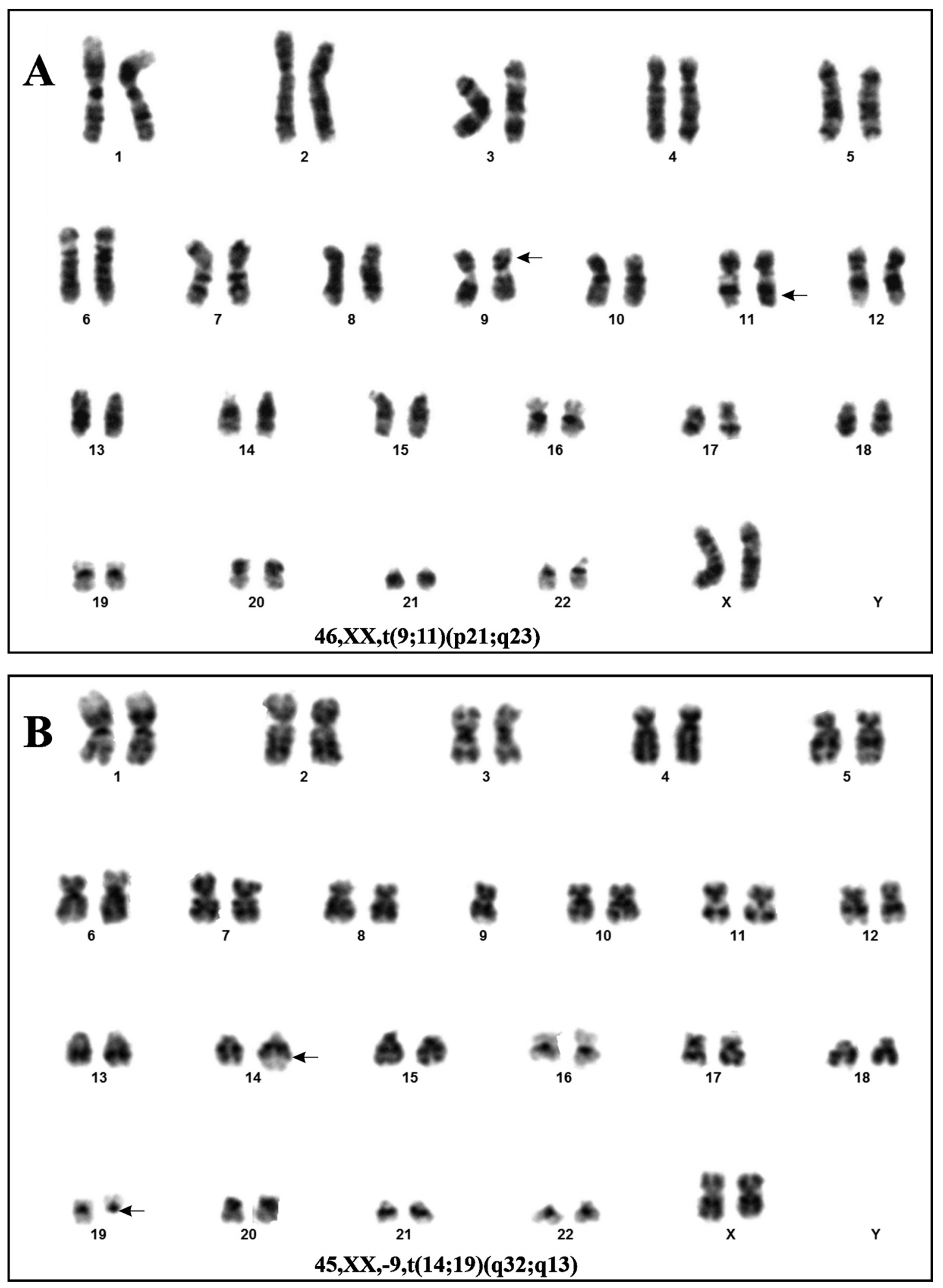

Figure 1. Cytogenetic analyses of the two pediatric leukemias. (A) Karyogram showing the $t(9 ; 11)(p 21 ; q 23)$ found at diagnosis, when the patient had acute myeloid leukemia (AML). (B) Karyogram showing the loss of chromosome 9 and the $1(14 ; 19)(q 32 ; q 13)$ found when the patient was diagnosed with acute lymphoblastic leukemia (ALL) 1,198 days after the initial AML. Breakpoint positions are indicated by arrows. 
FISH analyses. Three FISH analyses were performed at initial diagnosis of AML. Interphase FISH with the KMT2A breakapart probe showed a normal (yellow) as well as split (separated red and green) signals of the probe in 195 out of 204 examined nuclei (96\%) (Table I, sample S0) (Figure 2A). FISH analysis with a KMT2A-MLLT3 translocation dual fusion probe on metaphase spreads showed the KMT2A-MLLT3 and MLLT3KMT2A fusion genes on chromosomes $\operatorname{der}(11)$ and $\operatorname{der}(9)$, respectively (Figure 2B). Interphase FISH with the same KMT2A-MLLT3 translocation dual fusion probe showed a normal red signal corresponding to the MLLT3 gene, a normal green signal corresponding to the $K M T 2 A$ gene, and two yellow fusion signals corresponding to KMT2A-MLLT3 and MLLT3KMT2A in 184 out of 190 (97\%) examined nuclei (Figure 2C). In addition, at another diagnostic laboratory, a KMT2A-MLLT3 fusion transcript was detected (data not shown) which was in an agreement with the G-banding and interphase FISH results.

In the sample obtained 300 days after diagnosis, interphase FISH with a break-apart KMT2A probe for the first time showed loss of the distal part of the KMT2A probe, namely in 160 out of 200 nuclei ( $80 \%$ ) (Table I, sample S1, Figure 2D). This pattern with deletion or loss of the distal part of KMT2A has since persisted throughout the entire follow-up period (Table I, samples S1-S11-A) until the patient was transplanted. Deletion of the distal part of the KMT2A probe was also found in $77 \%$ of the CD34+CD117+ cells and in $34 \%$ of the negative fraction of the sorted cells 1,686 days after the diagnosis (Table I, samples S11-B and S11-C).

In the sample obtained 90 days after allogenic stem cell transplantation the KMT2A break-apart probe showed two normal (yellow) signals in 200 interphase nuclei (Table I, sample S12).

Interphase FISH with a KMT2A-MLLT3 translocation dual fusion probe on samples obtained 718 days and 914 days after the initial diagnosis did not detect any KMT2A-MLLT3 fusion in 200 examined nuclei (Table I, samples S6 and S7).

In the sample obtained 1,198 days after diagnosis, when a $\mathrm{t}(14 ; 19)(\mathrm{q} 32 ; \mathrm{q} 13)$ was seen by karyotyping and the patient had developed ALL, the FISH results were as follows: No KMT2A-MLLT3 fusion was seen in 200 nuclei, deletion of the distal part of the KMT2A probe was detected in 194 out of 200 nuclei (97\%) and on metaphase spreads (Figure 2E), and splitting of the $I G H$ probe was seen in 195 out of 211 (92\%) nuclei as well as on metaphase spreads (Figure $2 \mathrm{~F}$ and 2G) (Table I, sample S8). In the sample obtained 1,294 days after diagnosis, FISH analyses showed deletion of the distal part of the KMT2A probe in 17 out of 200 nuclei $(8.5 \%)$ and no split of $I G H$ in 200 nuclei (Table I, sample S9).

RNA-sequencing and molecular genetic confirmation of the fusion. After the G-banding/interphase FISH results were obtained from the sample drawn at day 1,539, we decided to perform retroactive RNA sequencing of the bone marrow sample obtained 389 days after the diagnosis. At that point in time (389 days), the G-banding analysis was normal whereas FISH with the break apart KMT2A probe showed deletion of the distal part of the probe in 184 out of 200 (92\%) examined nuclei (Table I, sample S3).

Using FusionCatcher on the raw sequencing data obtained from the Genomics Core Facility, a KMT2A-ARHGEF 12 fusion transcript was found in which exon 9 of $K M T 2 A$ (nt 4241 in sequences with accession numbers NM_005933.3 and NM_001197104.1) was fused to exon 14 of ARHGEF12 (nt 1428 in sequence with accession number NM_015313.2) (AATTCCAGCAGATGGAGTCCACAGGATCAGAGTGGA CTTTAAG*ATCAATGGACAGTGCAGCTGTTTCCAGAG CATTGAATTACTAA). No reciprocal ARHGEF 12-KMT2A fusion transcript was found.

RT-PCR and cycle Sanger sequencing with the primers M13For-MLL-4010F1/M13Rev-ARHGEF12-1579R1 and M13For-MLL-4115F1/M13Rev-ARHGEF12-1515R 1 confirmed the results obtained by RNA sequencing/Fusion Catcher analysis (Figure 3A).

Genomic PCR using as template DNA extracted from the patient's bone marrow cells sampled 1,198 days and 1,539 days after the initial diagnosis amplified a 1264 bp fragment with the primer combination MLL-4116-F1/ARHGEF121502-R1 and a 1133 bp fragment with the primer combination MLL-4202-F1/ARHGEF12-1437-R1 (Figure $3 \mathrm{~B}$ and $\mathrm{C})$. Direct sequencing showed that they were genomic KMT2A-ARHGEF12 chimeric fragments in which a sequence from intron 9 of $K M T 2 A$ was fused to a sequence of intron 13 from ARHGEF 12 (Figure 3D).

Neither RT-PCR nor genomic PCR detected KMT2AARHGEF12 chimeric fragments when the template was RNA (cDNA) or genomic DNA obtained from the diagnostic (day 0) bone marrow (Figure 3C).

aCGH analysis. aCGH detected a deletion in the $\mathrm{q}$ arm of chromosome 11 (Figure 4). Based on the hg19 assembly, the deletion was from the probe at position Chr11:118355288118355347 in $K M T 2 A$ to the probe at position Chr11:120290981-120291040 in ARHGEF12 (Figure 4). Thus, the aCGH data agreed with the results of FISH analyses, genomic PCR, and RT-PCR; they suggested that the KMT2A-ARHGEF12 fusion gene was the result of a deletion within chromosome band 11q23.

\section{Discussion}

A fusion of KMT2A with the ARHGEF 12 gene was first reported in a 38 -year-old male with a history of occupational exposure to herbicides who had developed AML (FAB-M4) and the abnormal karyotype $51, \mathrm{XY},+8,+19,+3 \operatorname{mar}(23)$. The patient received standard induction chemotherapy and achieved complete remission by morphological bone marrow 
KMT2A break-apart probe

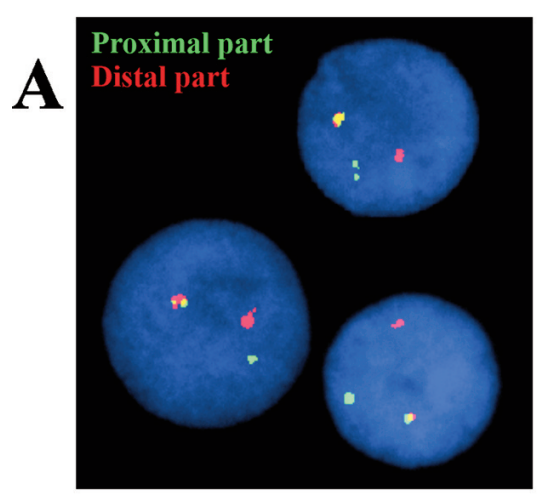

KMT2A-MLLT3 translocation dual fusion probe
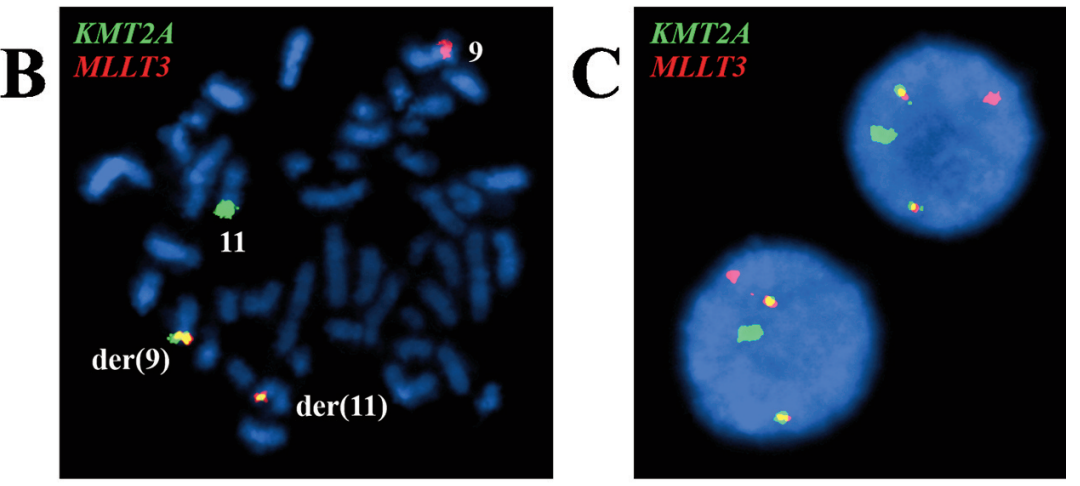

KMT2A break-apart probe
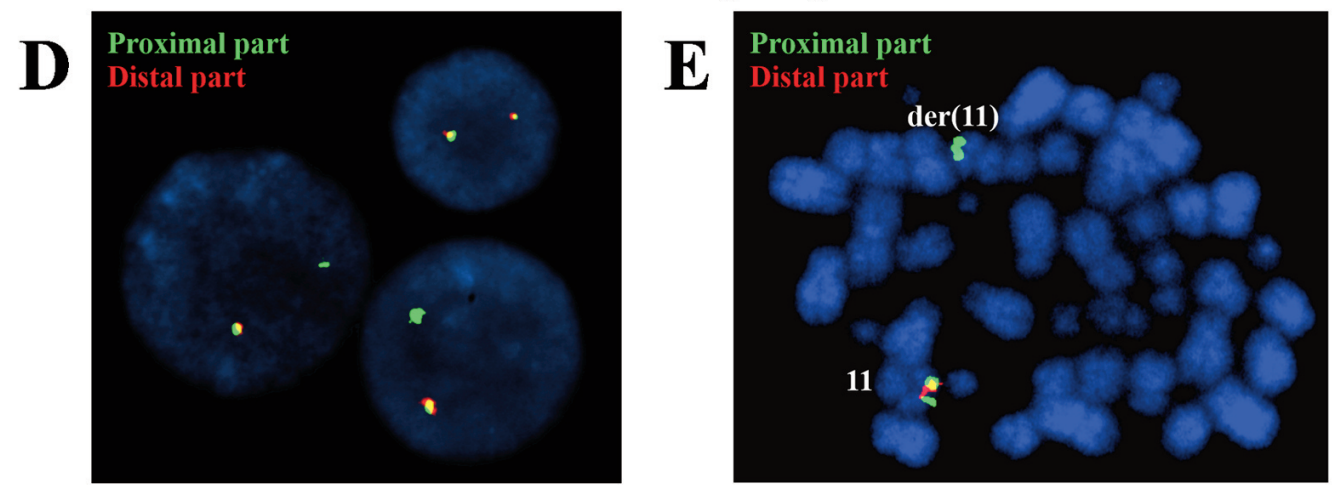

\section{IGH break-apart probe}
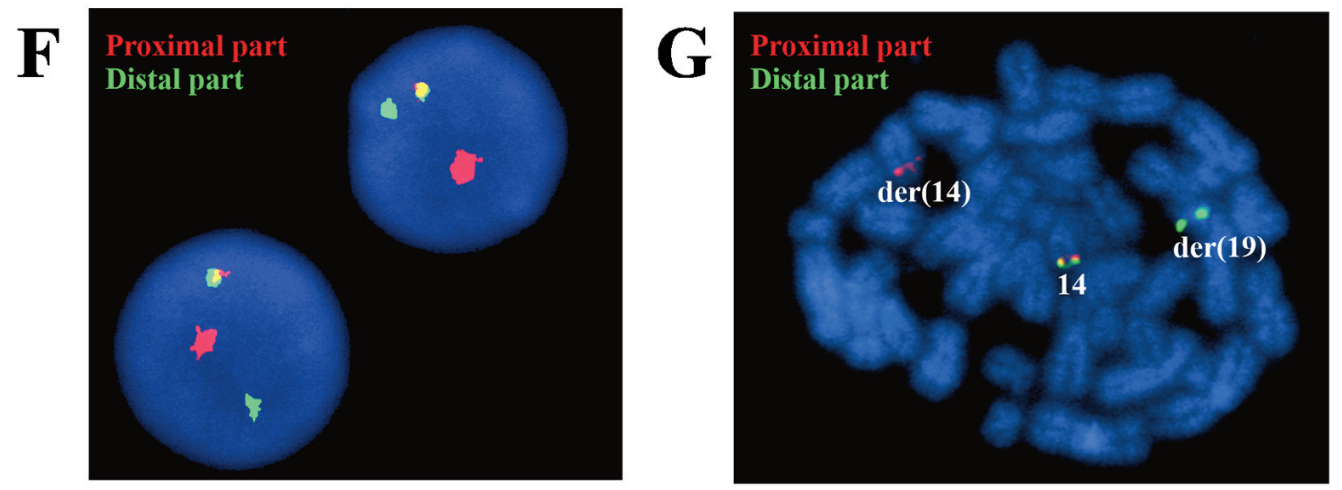

Figure 2. Fluorescence in situ hybridization (FISH) analyses of pediatric leukemia. (A) Interphase FISH at initial diagnosis of AML with the KMT2A break-apart probe showing a normal (yellow) and split (separated red and green) signals of the probe in 3 nuclei. (B) FISH analysis at initial diagnosis of AML with the KMT2A-MLLT3 translocation dual fusion probe on metaphase spreads showing a normal green signal on chromosome 11, corresponding to KMT2A, a normal red signal on chromosome 9, corresponding to MLLT3, and two yellow fusion signals on der(11) and der(9) corresponding to the KMT2A-MLLT3 and MLLT3-KMT2A fusion genes, respectively. (C) Interphase FISH at initial diagnosis of AML on two nuclei using the KMT2A-MLLT3 translocation dual fusion probe showing a normal green signal, corresponding to KMT2A, a normal red signal, corresponding to MLLT3, and two yellow fusion signals corresponding to the KMT2A-MLLT3 and MLLT3-KMT2A fusion genes. (D) Interphase FISH with the breakapart KMT2A probe on the sample obtained 300 days after diagnosis showing deletion of the distal part of the KMT2A probe (lack of red signal) in two nuclei and two normal (yellow) KMT2A signals in one nucleus. (E) FISH analysis with the break-apart KMT2A probe on metaphase spread from the sample obtained 1,198 days after diagnosis, when a $t(14 ; 19)(q 32 ; q 13)$ was seen by karyotyping and the patient had developed ALL. The distal part (red signal) of the probe is absent in one of the two copies of chromosome 11. (F) Interphase FISH with the IGH break-apart probe on the sample obtained 1,198 days after diagnosis, when a t(14;19)(q32;q13) was seen by karyotyping and the patient had developed ALL. A normal (yellow) and split (separated red and green) signals of the probe are shown in 2 nuclei. (G) FISH analysis with the IGH break-apart probe on a metaphase spread from the sample obtained 1,198 days after diagnosis, when a t(14;19)(q32;q13) was seen by karyotyping and the patient had developed ALL. A normal (yellow) signal on chromosome 14 together with separate red, on der(14), and green, on der(19), probe signals are shown. 


\section{A KMT2A exon $9 \quad \downarrow \quad A R H G E F 12$ exon 14}

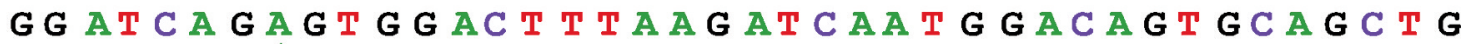

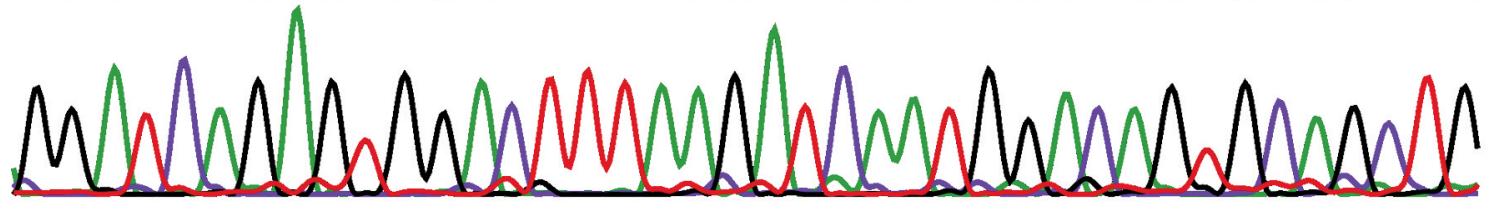
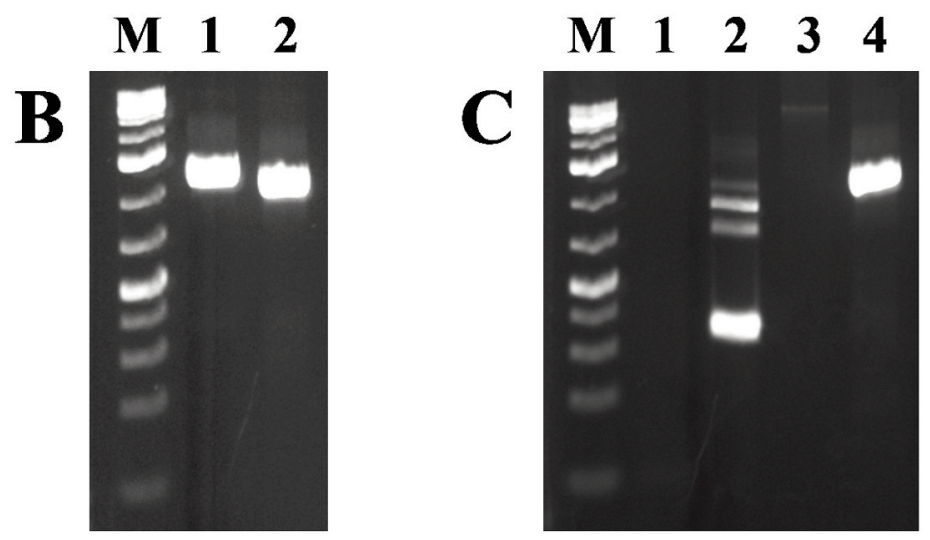

D KMT2A intron $9 \downarrow$ \RHGEF12 intron 13

CA G AG A A TA T T C C T TAC CAC T G A T T T GA T T T T T

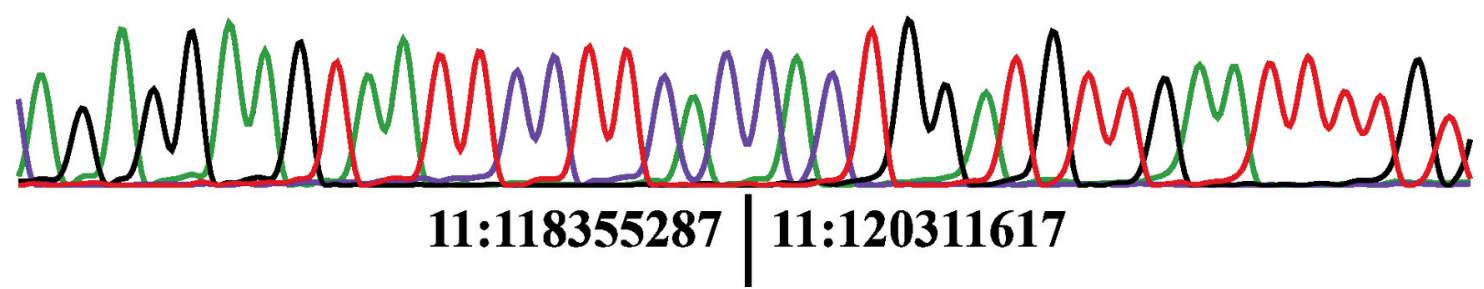

Figure 3. PCR analyses of the pediatric leukemias. (A) Partial sequence chromatogram showing the junction position of exon 9 of the KMT2A with exon 14 of ARHGEF12 in the chimeric transcript. (B) Gel electrophoresis showing the amplified KMT2A-ARHGEF12 genomic DNA fragment using two primer combinations and template DNA extracted from the patient's bone marrow cells 1,539 days after the initial diagnosis. Lane 1: Primer combination MLL-4116F1/ARHGEF12-1502R1. Lane 2: Primer combination MLL-4202-F1/ARHGEF12-1437-R1. (C) Gel electrophoresis showing the absence of amplified KMT2A-ARHGEF12 cDNA (lane 1) and genomic DNA (lane 3) fragments at diagnosis when the leukemic cells had $t(9 ; 11)(p 21 ; q 23)$ and a KMT2A-MLLT3 fusion gene, and the presence of KMT2A-ARHGEF12 in the patient's bone marrow cells 1,198 days after the initial diagnosis, when the patient had developed ALL with $t(14 ; 19)(q 32 ; q 13)$ and rearrangement of the IGH locus (lane 4). For both cDNA and genomic DNA amplifications, the primer combination MLL-4116F1/ARHGEF12-1502R1 was used. Lane 2: Assessment of the quality of cDNA synthesis by amplification of a cDNA fragment of ABL1 using the primer combination ABL1-91F1/ABL1-404R1. Lane 4: Amplification of a genomic KMT2AARHGEF12 DNA fragment in the patient's bone marrow cells 1,198 days after the initial diagnosis. M, GeneRuler 1 Kb Plus DNA ladder (ThermoFisher Scientific). (D) Partial sequence chromatogram showing the junction position of intron 9 of the KMT2A with intron 13 of ARHGEF12 in the chimeric amplified DNA fragment. The junction of positions 11:118355287-11:120311617 is based on the human genome GRCh37/hg19 assembly.

analysis, whereupon he received successful allogeneic bone marrow transplantation from an HLA identical sibling. He died 6 months later from interstitial pneumonia. There were no signs of relapse at autopsy (23).
The second case was a 77-year-old female with AML (FABM5a) and the karyotype 53,XX,+6,+8,+8,+9,+11,+13,+22 (24). The third patient with KMT2A-ARHGEF12 was an adult female with therapy-related AML (t-AML) (4, 5). No 


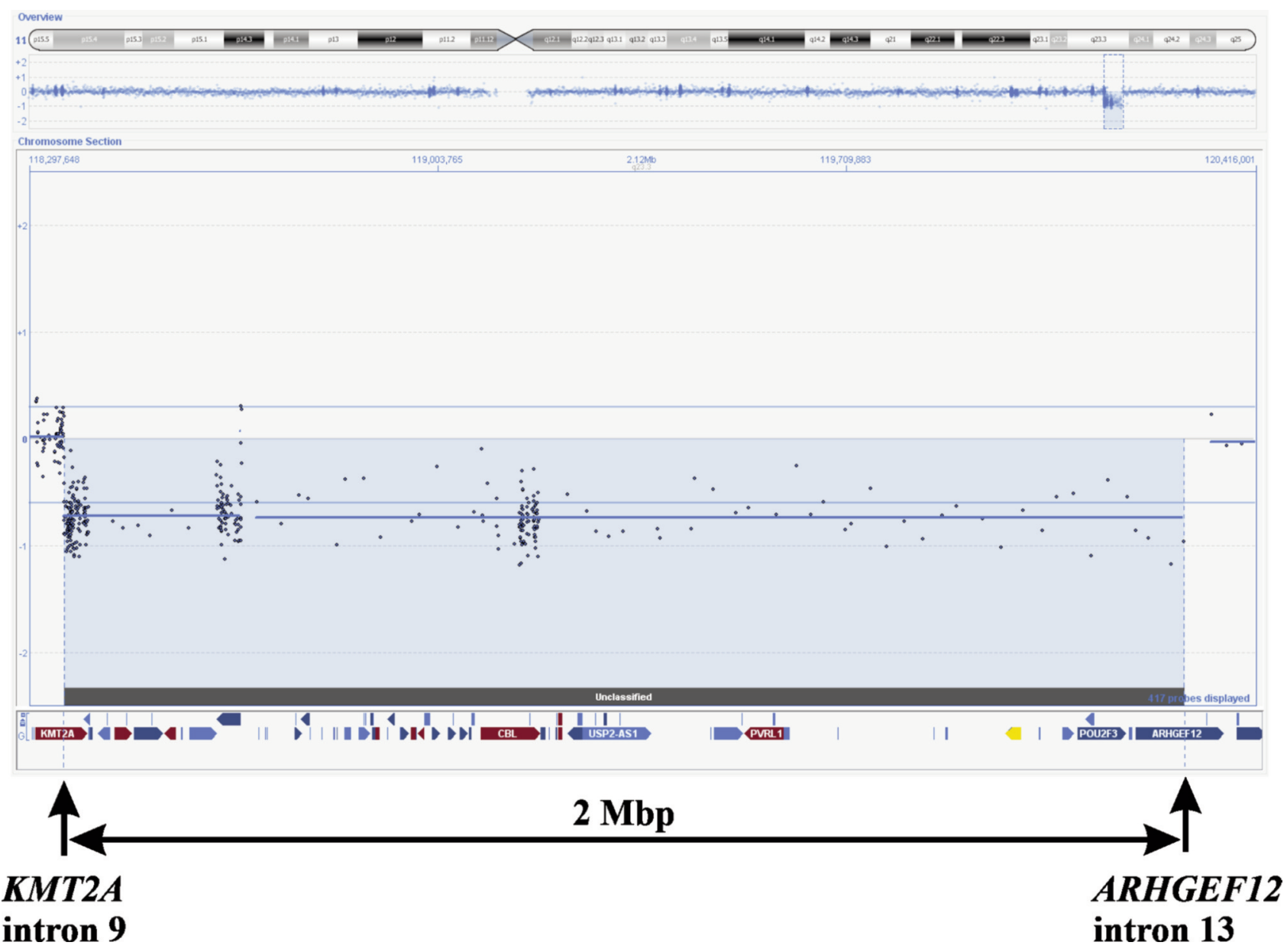

Figure 4. aCGH showing the deletion in the q arm of chromosome 11. Based on the hg19 assembly, the deletion started from the probe at position Chr11:118355288-118355347 in KMT2A and ended at position Chr11:120290981-120291040 in ARHGEF12. The deletion is approximately 2 Mbp.

information on the treatment and clinical outcome was provided for the second and third patients. The fourth patient with KMT2A-ARHGEF 12 fusion was a 69-year-old-male with B-cell ALL and a normal karyotype (25). This patient did not achieve complete remission after two courses of induction therapy and died from the disease (25). The fifth patient was a female with B-cell ALL and the bone marrow karyotype 46,XX, der(9)t(3;9)(p21;q34)/46,idem, der(9)t(3;9) (26). No further information was provided.

The present, sixth patient is the first reported pediatric case with a KMT2A-ARHGEF12 fusion gene. The fusion was detected in the patient's bone marrow after completion of treatment for an AML with $\mathrm{t}(9 ; 11)(\mathrm{p} 21 ; \mathrm{q} 23)$ and a KMT2A$M L L T 3$ fusion gene. The chemotherapy included, among other drugs, daunorubicin, mitoxantrone and etoposide which all are topoisomerase II inhibitors and associated with DNA doublestrand breaks, the generation of KMT2A rearrangements, the formation of $K M T 2 A$-fusion genes, and therapy-related acute leukemias (27-33). B-ALL with 11q23 abnormalities/KMT2A rearrangements developing after treatment of a primary malignancy with topoisomerase II inhibitors have been reported (34-40). The majority of cases had the $\mathrm{t}(4 ; 11)(\mathrm{q} 21 ; \mathrm{q} 23)$ translocation resulting in formation of a KMT2A-AFF1 fusion gene, but fusions of KMT2A with MLLT1 (19p13.3), FOXO3A (6q21), MAML2 (11q21), ACTN4 (19q13), CEP164 (11q23.3), and PRRC1 (5q23) were also found $(5,39)$. Therefore, we consider the chemotherapy to have caused the KMT2A-ARHGEF12 fusion.

The first indication of a KMT2A-ARHGEF 12 fusion gene was seen in the patient's bone marrow cells at days 300 and 328 after the initial AML diagnosis when, in FISH experiments, deletion of the distal part of the KMT2A probe was detected in spite of a normal karyotype (Table I, samples $\mathrm{S} 1$ and S2). RNA sequencing performed later detected the 
KMT2A-ARHGEF 12 fusion gene, PCR amplifications verified it both at the transcriptional and genomic level (Figure 3), and aCGH showed that the cause of the fusion was indeed a submicroscopic deletion starting in intron 9 of KMT2A extending to intron 13 of ARHGEF12 (Figure 4). These retrospective findings fit perfectly the early detection of a deleted distal part of the $K M T 2 A$ probe, linking it to the emergence of the KMT2A-ARHGEF12 fusion. Because the aberration was found in $77 \%$ of the CD34+CD117+ cells (Table I, sample S11-B), we concluded that the treatmentinduced generation of KMT2A-ARHGEF 12 fusion probably took place in a multipotent progenitor cell. Indeed, in vitro experiments have shown that etoposide-induced rearrangements of $K M T 2 A$ resulting in fusion genes can occur in mouse embryonic stem cells (27), human CD34+ hematopoietic stem cells from fetal liver (41), human CD34+ cells isolated from umbilical cord blood $(28,42)$, and in human embryonic stem cells (43). Furthermore, Libura et al. (42) showed that the etoposide-induced-KMT2A rearrangements were found at high frequency in human primitive hematopoietic stem cells with, in vitro and in vivo, long-term repopulating potential.

During a period of two years and three months (after completion of therapy of the initial AML), repeated bone marrow examinations were performed and in all of them, although there was no sign of malignancy, the genetic pattern was the same: normal karyotype and deletion of the distal part of the KMT2A probe in FISH experiments indicating, as we only later realized, the formation of KMT2A-ARHGEF 12 (Table 1, samples S1-S7). Searching the relevant literature, we found two reports describing similar findings to ours (44, 45). In the first, a 5-year-old girl was diagnosed with AML carrying a variant of $\mathrm{t}(8 ; 21)$ (44). The patient achieved clinical and hematologic remission which, 4 years later when the authors reported the case, was still unquestionable. Bone marrow examination 15 months after the intial diagnosis had revealed a clonal $\mathrm{t}(11 ; 11)(\mathrm{q} 13 ; \mathrm{q} 23)$, however, and the translocation gave rise to a KMT2A-ARHGEF 17 and the reciprocal ARHGEF17-KMT2A fusion genes (44). Retrospective PCR analysis did not detect any $K M T 2 A-$ ARHGEF 17 chimera in samples drawn at the time of diagnosis suggesting that the fusion was treatment-induced. The KMT2A aberration was found only in myeloid lineage cells and in numerous samples over a 30-month period without simultaneous phenotypic signs of a new malignancy. Because myeloid cells as mature as promyelocytes and even differentiated polymorphonuclear neutrophils carried the KMT2A-ARHGEF 17, the authors concluded that the fusion had probably occurred in a myeloid stem cell but without blocking further differentiation (44).

The second case was a 3 -year-old boy with B-ALL and a hyperdiploid karyotype: $58<2 \mathrm{n}>, \mathrm{XY},+\mathrm{X},+4,+6,+10,+15$, $+17,+18,+18,+20,+21,+21,+22$ (45). During chemotherapy, a $\mathrm{t}(3 ; 11)(\mathrm{p} 21 ; \mathrm{q} 23)$ developed in bone marrow cells giving rise to a KMT2A-SACM1L fusion gene. The KMT2A$S A C M 1 L$ fusion was detected in many samples over a 7-year period in which the patient was in hematological remission. A difference between the KMT2A-ARHGEF17 and KMT2A$S A C M 1 L$ fusion genes was that whereas the first resulted in a KMT2A-ARHGEF17 fusion protein, the second encodes a truncated KMT2A protein $(44,45)$.

Our patient was, two years and nine months after the start of the last AML chemotherapy course (or 3 years and 3 months after the initial diagnosis of AML), diagnosed with BALL (Table I, sample S8). The bone marrow contained 90\% blasts of the pre-B phenotype, cytogenetic analysis revealed a $\mathrm{t}(14 ; 19)(\mathrm{q} 32 ; \mathrm{q} 13)$ translocation together with loss of one chromosome 9 (Figure 1B, Table I, sample S8, see below), and FISH analyses showed splitting of the IGH probe in $92 \%$ of the nuclei together with deletion of the distal part of the $K M T 2 A$ probe in $97 \%$ of the nuclei. In addition, later molecular analysis demonstrated presence of the KMT2A$A R H G E F 12$ fusion gene also at this time. Given the fact that so many bone marrow cells had the aberrations, most of them must have had both, leading us to conclude that the $\mathrm{t}(14 ; 19)(\mathrm{q} 32 ; \mathrm{q} 13)$ translocation and loss of one chromosome 9 were secondary to the submicroscopic deletion in 11q23. Three months after treatment for B-ALL had been instituted, the $(14 ; 19)(\mathrm{q} 32 ; \mathrm{q} 13) / I G H$ aberration was no longer detectable while the KMT2A rearrangement was found in only $8.5 \%$ of the examined interphase nuclei. Evidently, the treatment given had considerable effect also on the cells carrying KMT2A rearrangement, but not enough to completely eradicate them. Summing up the extensive and somewhat complicating data the high frequency of $\mathrm{t}(14 ; 19)(\mathrm{q} 32 ; \mathrm{q} 13) / I G H$ rearrangement and KMT2A rearrangement in bone marrow cells when the patient developed B-ALL, and the absence of $\mathrm{t}(14 ; 19)(\mathrm{q} 32 ; \mathrm{q} 13) / I G H$ rearrangement together with the low frequency of $K M T 2 A$ rearrangement after treatment for this disease - strongly indicate that (most of) the cells carrying KMT2A-rearrangement were part of the leukemic clone which carried the $\mathrm{t}(14 ; 19)(\mathrm{q} 32 ; \mathrm{q} 13) / I G H$ rearrangement when the patient had B-ALL.

Our data are also in agreement with the findings reported by Jeffries et al. (46). Examining 20 B-ALL patients, they showed that translocations involving the IGH locus coexisted with other primary chromosomal rearrangements either in the same or separate clones. In one of the studied patients, $K M T 2 A$ rearrangement was the primary aberration whereas the $I G H$-translocation the secondary. Most cells had only $K M T 2 A$ rearrangement but cells with only $I G H$-translocation and cells with both $K M T 2 A$ aberration and IGH-translocation were also found (46).

The case we present has extensive similarities with the case reported by Zuna et al. (47). In brief, a 15-year-old girl with acute promyelocytic leukemia (APL, AML-M3) carrying 
a PML-RARA fusion gene together with internal tandem duplication of FLT3 (FLT3/ITD) was treated with drugs that included the topoisomerase II inhibitors idarubicin and etoposide. Thirty months after the diagnosis of APL and 13 months after completion of therapy, she was diagnosed with B-ALL. Cytogenetic analysis revealed a t(6;11)(q21;q23) translocation aberration with molecular analyses showing the presence of a KMT2A-FOXO3A fusion gene whereas both $P M L-R A R A$ fusion gene and FLT3/ITD were absent (47).

Backtracking the B-ALL, just as we did in the present study, the authors found the KMT2A-FOXO3A fusion gene in up to $90 \%$ of bone marrow cells, including cells of the myeloid lineage, more than one year before the B-ALL diagnosis which suggested that the generation of the KMT2A-FOXO3A fusion occurred in a multipotent progenitor. During this preleukemic phase, no blasts were found in the bone marrow but a small population of CD19+ B-cells, comprising $0.2 \%$ of the bone marrow, was detected (47). In our case, similarly a small persisting aberrant CD34+, CD38+ cell population, decreasing in a proportion from $1.5 \%$ to $0.05 \%$ over eight months, was found whereas the deletion of the distal part of KMT2A was found in 79$92 \%$ of the cells (Table 1, samples S1-S7).

Zuna et al. (47) identified a $10 \mathrm{Mb}$ gain on $19 \mathrm{q} 13.32$ as a potential "second hit" for the development of the B-ALL. The gain was present in B-ALL but was not found in the preleukemic specimen. By analogy, in our case $\mathrm{t}(14 ; 19)(\mathrm{q} 32 ; \mathrm{q} 13)$ and loss of one chromosome 9 were secondary aberrations found at diagnosis of ALL but not in any previously examined samples (Table I, samples S1-S8).

Our patient also has similarities with the case presented by Jonveaux et al (48): A 35-year-old male had an AML (FAB M5b) with the chromosome aberration $\mathrm{t}(6 ; 11)(\mathrm{q} 27 ; \mathrm{q} 23)$. FISH analysis showed that presence of a 400-600 kbp deletion downstream of the 11q23 breakpoint. Using Southern blot methodology, the breakpoint of KMT2A was found within intron 7 of the gene. The patient received chemotherapy which, among the drugs, included mitoxantrone and etoposide. Ten and a half months after complete remission, he was diagnosed with B-ALL. The cytogenetic analysis now revealed a $\mathrm{t}(4 ; 11)(\mathrm{q} 21 ; \mathrm{q} 23)$ chromosome translocation, FISH showed absence of the deletion, and Southern blot detected a breakpoint in intron 9 of $K M T 2 A$ (48). The authors considered etoposide as responsible for the development of the secondary B-ALL.

At the transcription level, the fusion of the present case was found to recombine exon 9 of KMT2A with exon 14 of $A R H G E F 12$. This is at odds with what was reported by Kourlas et al. (23) who found fusion between exons 8 of KMT2A and 12 of ARHGEF12. No information on the exact KMT2A-ARHGEF 12 fusion point was given for the other three reported patients $(4,5,24,25)$. The KMT2A$A R H G E F 12$ fusion of the present patient was brought about by a $2 \mathrm{Mbp}$ deletion stretching from intron 9 of $K M T 2 A$ to intron 13 of $A R H G E F 12$. Deletions were also reported as the cause of KMT2A-ARHGEF12 formation in the patients described by Kourlas (23) and Meyer $(4,5)$.

The exact genomic breakpoint position in KMT2A has been shown to correlate with clinical outcome in acute leukemias caused by fusions between KMT2A and some of the more common partner genes $(5,49,50)$. Breakpoints in intron 10 (listed as intron 11 in the references $(5,49,50)$ ) interfere with the dimerization capacity of KMT2A plant homeodomains (PHD) 1-3, disabling binding to the BMI1 (B cell-specific Moloney murine leukemia virus integration site 1) repressor complex, and are associated with worse prognosis $(5,49-51)$. Breakpoints within KMT2A introns 8 and 9 (introns 9 and 10 in references $(5,49,50)$, on the other hand, do not affect the three PHD finger domains and are associated with somewhat better clinical outcomes. The breakpoint in intron 9 of the present case could explain the relatively benign clinical behavior observed with long-term survival in spite of the late detection of a KMT2A-ARHGEF 12 fusion gene and the therapy-related leukemia it signals.

The ARHGEF 12 gene codes for the Rho guanine nucleotide exchange factor 12 which is a guanine nucleotide exchange factor that activates small GTPases of the Rho family (see RHOA, 165390) and catalyzes the exchange of GDP for GTP (52-54). ARHGEF12 was shown to be involved in cell polarization, morphology, invasion, and cytokinetic abscission (55-61). ARHGEF12 together with ARHGEF2 (also known as GEF-H1) were found to be key molecules for cellular adaptation to force and regulate the mechanical response to force on integrins (62). ARHGEF12 was found to regulate human megakaryocyte maturation, is critical for platelet function, regulates erythropoiesis, and is involved in erythroid regeneration after chemotherapy in ALL patients $(63,64)$. ARHGEF 12 was also reported as a candidate tumor suppressor gene in breast and colorectal cancers (65). Mutations in the coding region of the gene are registered in COSMIC, the catalogue of somatic mutations in cancer (cancer.sanger.ac.uk), in various disease types (66).

In conclusion, we herein report the complex and sequential genetic steps of a therapy-related pediatric BALL. The patient was initially diagnosed with AML carrying a $\mathrm{t}(9 ; 11)(\mathrm{p} 21 ; \mathrm{q} 23)$ chromosome translocation and a $K M T 2 A-$ MLLT3 fusion gene. The first secondary genetic step, resulting from chemotherapy that included treatment with topoisomerase II-inhibitors, was a submicroscopic $2 \mathrm{Mb}$ deletion in 11q23 generating a KMT2A-ARHGEF12 fusion gene in a multipotent progenitor cell. At that point, the patient entered a long "preleukemic" phase which lasted until yet another genetic aberration occurred, $t(14 ; 19)(q 32 ; q 13)$ accompanied by the loss of one chromosome 9 . This resulted in the development of B-ALL. 


\section{Conflicts of Interest}

The Authors declare that they have no potential conflicts of interest in regard to this study.

\section{Authors' Contributions}

IP designed and supervised the experiments, performed bioinformatics analysis, molecular genetic experiments, evaluated the data, and drafted the manuscript. KA performed cytogenetic, FISH and molecular experiments and evaluated the data. ME-O evaluated the cytogenetic and FISH data. BZ made clinical evaluations and treated the patient. MCM-K made clinical evaluations and treated the patient. JB made clinical evaluations and treated the patient. LTNO performed the flow cytometric evaluations. FM evaluated the cytogenetic and FISH data. SH evaluated the data and assisted with writing of the manuscript. All Authors read and approved the final manuscript.

\section{Acknowledgements}

This work was supported by Grants from Radiumhospitalets Legater.

\section{References}

1 Daser A and Rabbitts TH: The versatile mixed lineage leukaemia gene MLL and its many associations in leukaemogenesis. Semin Cancer Biol 15(3): 175-188, 2005. PMID: 15826832. DOI: 10.1016/j.semcancer.2005.01.007

2 Marschalek R: Mechanisms of leukemogenesis by MLL fusion proteins. Br J Haematol 152(2): 141-154, 2011. PMID: 21118195. DOI: $10.1111 / j .1365-2141.2010 .08459 . x$

3 Mitelman F, Johansson B and Mertens F: Mitelman Database of Chromosome Aberrations and Gene Fusions in Cancer, 2020. Available at: https://mitelmandatabase.isb-cgc.org/

4 Meyer C, Hofmann J, Burmeister T, Groger D, Park TS, Emerenciano M, Pombo de Oliveira M, Renneville A, Villarese P, Macintyre E, Cave H, Clappier E, Mass-Malo K, Zuna J, Trka J, De Braekeleer E, De Braekeleer M, Oh SH, Tsaur G, Fechina L, van der Velden VH, van Dongen JJ, Delabesse E, Binato R, Silva ML, Kustanovich A, Aleinikova O, Harris MH, Lund-Aho T, Juvonen V, Heidenreich O, Vormoor J, Choi WW, Jarosova M, Kolenova A, Bueno C, Menendez P, Wehner S, Eckert C, Talmant P, Tondeur S, Lippert E, Launay E, Henry C, Ballerini $\mathrm{P}$, Lapillone $\mathrm{H}$, Callanan MB, Cayuela JM, Herbaux C, Cazzaniga G, Kakadiya PM, Bohlander S, Ahlmann M, Choi JR, Gameiro P, Lee DS, Krauter J, Cornillet-Lefebvre P, Te Kronnie G, Schafer BW, Kubetzko S, Alonso CN, zur Stadt U, Sutton R, Venn NC, Izraeli S, Trakhtenbrot L, Madsen HO, Archer P, Hancock J, Cerveira N, Teixeira MR, Lo Nigro L, Moricke A, Stanulla M, Schrappe M, Sedek L, Szczepanski T, Zwaan CM, Coenen EA, van den Heuvel-Eibrink MM, Strehl S, Dworzak M, Panzer-Grumayer R, Dingermann $\mathrm{T}$, Klingebiel $\mathrm{T}$ and Marschalek R: The MLL recombinome of acute leukemias in 2013. Leukemia 27(11): 2165-2176, 2013. PMID: 23628958. DOI: $10.1038 /$ leu.2013.135

5 Meyer C, Burmeister T, Groger D, Tsaur G, Fechina L, Renneville A, Sutton R, Venn NC, Emerenciano M, Pombo-deOliveira MS, Barbieri Blunck C, Almeida Lopes B, Zuna J, Trka
J, Ballerini P, Lapillonne H, De Braekeleer M, Cazzaniga G, Corral Abascal L, van der Velden VHJ, Delabesse E, Park TS, Oh SH, Silva MLM, Lund-Aho T, Juvonen V, Moore AS, Heidenreich O, Vormoor J, Zerkalenkova E, Olshanskaya Y, Bueno C, Menendez P, Teigler-Schlegel A, Zur Stadt U, Lentes J, Gohring G, Kustanovich A, Aleinikova O, Schafer BW, Kubetzko S, Madsen HO, Gruhn B, Duarte X, Gameiro P, Lippert E, Bidet A, Cayuela JM, Clappier E, Alonso CN, Zwaan CM, van den Heuvel-Eibrink MM, Izraeli S, Trakhtenbrot L, Archer P, Hancock J, Moricke A, Alten J, Schrappe M, Stanulla M, Strehl S, Attarbaschi A, Dworzak M, Haas OA, PanzerGrumayer R, Sedek L, Szczepanski T, Caye A, Suarez L, Cave $\mathrm{H}$ and Marschalek R: The MLL recombinome of acute leukemias in 2017. Leukemia 32(2): 273-284, 2018. PMID: 28701730. DOI: 10.1038/leu.2017.213

6 Heim S and Mitelman F: Cancer Cytogenetics: Chromosomal and Molecular Genetic Abberations of Tumor Cells. Fourth Edition edn. Wiley-Blackwell, 2015.

7 Winters AC and Bernt KM: MLL-rearranged leukemias-an update on science and clinical approaches. Front Pediatr 5: 4, 2017. PMID: 28232907. DOI: 10.3389/fped.2017.00004

8 De Braekeleer E, Meyer C, Douet-Guilbert N, Morel F, Le Bris MJ, Marschalek R, Ferec C and De Braekeleer M: A complex $1 ; 19 ; 11$ translocation involving the MLL gene in a patient with congenital acute monoblastic leukemia identified by molecular and cytogenetic techniques. Ann Hematol 88(8): 795-797, 2009. PMID: 19107484. DOI: 10.1007/s00277-008-0656-8

9 De Braekeleer E, Meyer C, Douet-Guilbert N, Basinko A, Le Bris MJ, Morel F, Berthou C, Marschalek R, Ferec C and De Braekeleer M: Identification of MLL partner genes in 27 patients with acute leukemia from a single cytogenetic laboratory. Mol Oncol 5(6): 555-563, 2011. PMID: 21900057. DOI: 10.1016/ j.molonc.2011.08.003

10 De Braekeleer E, Douet-Guilbert N, Meyer C, Morel F, Marschalek R and De Braekeleer M: MLL-ELL fusion gene in two infants with acute monoblastic leukemia and myeloid sarcoma. Leuk Lymphoma 53(6): 1222-1224, 2012. PMID: 22149207. DOI: $10.3109 / 10428194.2011 .648632$

11 Panagopoulos I, Gorunova L, Kerndrup G, Spetalen S, Tierens A, Osnes LT, Andersen K, Muller LS, Hellebostad M, Zeller B and Heim S: Rare MLL-ELL fusion transcripts in childhood acute myeloid leukemia-association with young age and myeloid sarcomas? Exp Hematol Oncol 5: 8, 2015. PMID: 26949571. DOI: $10.1186 / \mathrm{s} 40164-016-0037-2$

12 Zwaan CM, Kolb EA, Reinhardt D, Abrahamsson J, Adachi S, Aplenc R, De Bont ES, De Moerloose B, Dworzak M, Gibson BE, Hasle H, Leverger G, Locatelli F, Ragu C, Ribeiro RC, Rizzari C, Rubnitz JE, Smith OP, Sung L, Tomizawa D, van den Heuvel-Eibrink MM, Creutzig U and Kaspers GJ: Collaborative efforts driving progress in pediatric acute myeloid leukemia. J Clin Oncol 33(27): 2949-2962, 2015. PMID: 26304895. DOI: 10.1200/JCO.2015.62.8289

13 Toft N, Birgens H, Abrahamsson J, Griskevicius L, Hallbook H, Heyman M, Klausen TW, Jonsson OG, Palk K, Pruunsild K, Quist-Paulsen P, Vaitkeviciene G, Vettenranta K, Asberg A, Frandsen TL, Marquart HV, Madsen HO, Noren-Nystrom U and Schmiegelow K: Results of NOPHO ALL2008 treatment for patients aged 1-45 years with acute lymphoblastic leukemia. Leukemia 32(3): 606-615, 2018. PMID: 28819280. DOI: $10.1038 /$ leu.2017.265 
14 Panagopoulos I, Gorunova L, Torkildsen S, Tjonnfjord GE, Micci F and Heim S: DEK-NUP214-fusion identified by RNAsequencing of an acute myeloid leukemia with $\mathrm{t}(9 ; 12)(\mathrm{q} 34 ; \mathrm{q} 15)$. Cancer Genomics Proteomics 14(6): 437-443, 2017. PMID: 29109093. DOI: $10.21873 / \operatorname{cgp} .20053$

15 Schroeder A, Mueller O, Stocker S, Salowsky R, Leiber M, Gassmann M, Lightfoot S, Menzel W, Granzow M and Ragg T: The RIN: an RNA integrity number for assigning integrity values to RNA measurements. BMC Mol Biol 7: 3, 2006. PMID: 16448564 . DOI: 10.1186/1471-2199-7-3

16 Torkildsen S, Brunetti M, Gorunova L, Spetalen S, Beiske K, Heim S and Panagopoulos I: Rearrangement of the chromatin organizer special AT-rich binding protein 1 gene, SATB1, resulting from a $\mathrm{t}(3 ; 5)(\mathrm{p} 24 ; \mathrm{q} 14)$ chromosomal translocation in acute myeloid leukemia. Anticancer Res 37(2): 693-698, 2017. PMID: 28179318. DOI: 10.21873/anticanres.11365

17 Kangaspeska S, Hultsch S, Edgren H, Nicorici D, Murumagi A and Kallioniemi O: Reanalysis of RNA-sequencing data reveals several additional fusion genes with multiple isoforms. PLoS One 7(10): e48745, 2012. PMID: 23119097. DOI: 10.1371/journal.pone. 0048745

18 Nicorici D, Satalan H, Edgren H, Kangaspeska S, Murumagi A, Kallioniemi O, Virtanen S and Kikku O: FusionCatcher - a tool for finding somatic fusion genes in paired-end RNA-sequencing data. bioRxiv, 2014. DOI: 10.1101/011650

19 Singhal H, Ren YR and Kern SE: Improved DNA electrophoresis in conditions favoring polyborates and lewis acid complexation. PLoS One 5(6): e11318, 2010. PMID: 20593002. DOI: 10.1371/journal.pone.0011318

20 Altschul SF, Gish W, Miller W, Myers EW and Lipman DJ: Basic local alignment search tool. J Mol Biol 215(3): 403-410, 1990. PMID: 2231712. DOI: 10.1016/S0022-2836(05)80360-2

21 Kent WJ: BLAT - the BLAST-like alignment tool. Genome Res 12(4): 656-664, 2002. PMID: 11932250. DOI: 10.1101/gr.229202

22 Kent WJ, Sugnet CW, Furey TS, Roskin KM, Pringle TH, Zahler $\mathrm{AM}$ and Haussler D: The human genome browser at UCSC. Genome Res 12(6): 996-1006, 2002. PMID: 12045153. DOI: $10.1101 /$ gr.229102

23 Kourlas PJ, Strout MP, Becknell B, Veronese ML, Croce CM, Theil KS, Krahe R, Ruutu T, Knuutila S, Bloomfield CD and Caligiuri MA: Identification of a gene at 11q23 encoding a guanine nucleotide exchange factor: evidence for its fusion with MLL in acute myeloid leukemia. Proc Natl Acad Sci USA 97(5): 21452150, 2000. PMID: 10681437. DOI: 10.1073/pnas.040569197

24 Shih LY, Liang DC, Fu JF, Wu JH, Wang PN, Lin TL, Dunn P, Kuo MC, Tang TC, Lin TH and Lai CL: Characterization of fusion partner genes in 114 patients with de novo acute myeloid leukemia and MLL rearrangement. Leukemia 20(2): 218-223, 2006. PMID: 16341046. DOI: 10.1038/sj.leu.2404024

25 Liu YF, Wang BY, Zhang WN, Huang JY, Li BS, Zhang M, Jiang L, Li JF, Wang MJ, Dai YJ, Zhang ZG, Wang Q, Kong J, Chen B, Zhu YM, Weng XQ, Shen ZX, Li JM, Wang J, Yan XJ, Li Y, Liang YM, Liu L, Chen XQ, Zhang WG, Yan JS, Hu JD, Shen SH, Chen J, Gu LJ, Pei D, Li Y, Wu G, Zhou X, Ren RB, Cheng C, Yang JJ, Wang KK, Wang SY, Zhang J, Mi JQ, Pui CH, Tang JY, Chen Z and Chen SJ: Genomic profiling of adult and pediatric B-cell acute lymphoblastic leukemia. EBioMedicine 8: 173-183, 2016. PMID: 27428428. DOI: 10.1016/j.ebiom.2016.04.038

26 Sevov M, Bunikis I, Häggqvist S, Höglund M, Rosenquist R, Ameur A and Cavelier L: Targeted RNA sequencing assay efficiently identifies cryptic KMT2A (MLL)-fusions in acute leukemia patients. Blood 124(21): 2406-2406, 2014. DOI: 10.1182/blood.V124.21.2406.2406

27 Blanco JG, Edick MJ and Relling MV: Etoposide induces chimeric Mll gene fusions. FASEB J 18(1): 173-175, 2004. PMID: 14630694. DOI: 10.1096/fj.03-0638fje

28 Libura J, Slater DJ, Felix CA and Richardson C: Therapy-related acute myeloid leukemia-like MLL rearrangements are induced by etoposide in primary human CD34+ cells and remain stable after clonal expansion. Blood 105(5): 2124-2131, 2005. PMID: 15528316. DOI: 10.1182/blood-2004-07-2683

29 Felix CA, Kolaris CP and Osheroff N: Topoisomerase II and the etiology of chromosomal translocations. DNA Repair 5(9-10): 1093-1108, 2006. PMID: 16857431. DOI: 10.1016/j.dnarep. 2006.05.031

30 Sung PA, Libura J and Richardson C: Etoposide and illegitimate DNA double-strand break repair in the generation of MLL translocations: new insights and new questions. DNA Repair 5(910): 1109-1118, 2006. PMID: 16809075. DOI: 10.1016/j.dnarep. 2006.05.018

31 Cowell IG and Austin CA: Mechanism of generation of therapy related leukemia in response to anti-topoisomerase II agents. Int J Environ Res Public Health 9(6): 2075-2091, 2012. PMID: 22829791. DOI: $10.3390 /$ ijerph9062075

32 Ezoe S: Secondary leukemia associated with the anti-cancer agent, etoposide, a topoisomerase II inhibitor. Int J Environ Res Public Health 9(7): 2444-2453, 2012. PMID: 22851953. DOI: 10.3390/ijerph9072444

33 Evison BJ, Sleebs BE, Watson KG, Phillips DR and Cutts SM: Mitoxantrone, more than just another topoisomerase II poison. Med Res Rev 36(2): 248-299, 2016. PMID: 26286294. DOI: 10.1002/med.21364

34 Pagano L, Pulsoni A, Tosti ME, Annino L, Mele A, Camera A, Martino B, Guglielmi C, Cerri R, Di Bona E, Invernizzi R, Castagnola C, Bassan R, Mele L, Todeschini G, Leone G and Mandelli F: Acute lymphoblastic leukaemia occurring as second malignancy: report of the GIMEMA archive of adult acute leukaemia. Gruppo Italiano Malattie Ematologiche Maligne dell'Adulto. Br J Haematol 106(4): 1037-1040, 1999. PMID: 10520009. DOI: 10.1046/j.1365-2141.1999.01636.x

35 Ishizawa S, Slovak ML, Popplewell L, Bedell V, Wrede JE, Carter NH, Snyder DS and Arber DA: High frequency of pro-B acute lymphoblastic leukemia in adults with secondary leukemia with 11q23 abnormalities. Leukemia 17(6): 1091-1095, 2003. PMID: 12764373. DOI: 10.1038/sj.leu.2402918

36 Shivakumar R, Tan W, Wilding GE, Wang ES and Wetzler M: Biologic features and treatment outcome of secondary acute lymphoblastic leukemia - a review of 101 cases. Ann Oncol 19(9): 1634-1638, 2008. PMID: 18467310. DOI: 10.1093/annonc/mdn 182

37 Abdulwahab A, Sykes J, Kamel-Reid S, Chang H and Brandwein JM: Therapy-related acute lymphoblastic leukemia is more frequent than previously recognized and has a poor prognosis. Cancer 118(16): 3962-3967, 2012. PMID: 22180297. DOI: $10.1002 / \mathrm{cncr} .26735$

38 Tang G, Zuo Z, Thomas DA, Lin P, Liu D, Hu Y, Kantarjian HM, Bueso-Ramos C, Medeiros LJ and Wang SA: Precursor Bacute lymphoblastic leukemia occurring in patients with a history of prior malignancies: is it therapy-related? Haematologica 97(6): 919-925, 2012. PMID: 22207681. DOI: 10.3324/haematol.2011.057752 
39 Douet-Guilbert N, Eveillard JR, Meyer C, Ugo V, Le Bris MJ, Basinko A, Morel F, Marschalek R and De Braekeleer M: MLL partner genes in secondary acute lymphoblastic leukemia: report of a new partner PRRC1 and review of the literature. Leuk Res 38(11): 1316-1319, 2014. PMID: 25205603. DOI: 10.1016/ j.leukres.2014.08.011

40 Aldoss I, Douer D and Pullarkat V: Therapy-related acute lymphoblastic leukemia: Where do we stand with regards to its definition and characterization? Blood Rev 37: 100584, 2019. PMID: 31235377. DOI: 10.1016/j.blre.2019.06.001

41 Moneypenny CG, Shao J, Song Y and Gallagher EP: MLL rearrangements are induced by low doses of etoposide in human fetal hematopoietic stem cells. Carcinogenesis 27(4): 874-881, 2006. PMID: 16377807. DOI: 10.1093/carcin/bgi322

42 Libura J, Ward M, Solecka J and Richardson C: Etoposideinitiated MLL rearrangements detected at high frequency in human primitive hematopoietic stem cells with in vitro and in vivo long-term repopulating potential. Eur J Haematol 81(3): 185-195, 2008. PMID: 18510699. DOI: 10.1111/j.1600-0609.2008.01103.x

43 Bueno C, Catalina P, Melen GJ, Montes R, Sanchez L, Ligero G, Garcia-Perez JL and Menendez P: Etoposide induces MLL rearrangements and other chromosomal abnormalities in human embryonic stem cells. Carcinogenesis 30(9): 1628-1637, 2009. PMID: 19587093. DOI: 10.1093/carcin/bgp169

44 Teuffel O, Betts DR, Thali M, Eberle D, Meyer C, Schneider B, Marschalek R, Trakhtenbrot L, Amariglio N, Niggli FK and Schafer BW: Clonal expansion of a new MLL rearrangement in the absence of leukemia. Blood 105(10): 4151-4152, 2005. PMID: 15867425. DOI: 10.1182/blood-2005-01-0286

45 Mori T, Nishimura N, Hasegawa D, Kawasaki K, Kosaka Y, Uchide K, Yanai T, Hayakawa A, Takeshima Y, Nishio H and Matsuo M: Persistent detection of a novel MLL-SACM1L rearrangement in the absence of leukemia. Leuk Res 34(10): 13981401, 2010. PMID: 20553989. DOI: 10.1016/j.leukres.2010.05.001

46 Jeffries SJ, Jones L, Harrison CJ and Russell LJ: IGH@ translocations co-exist with other primary rearrangements in Bcell precursor acute lymphoblastic leukemia. Haematologica 99(8): 1334-1342, 2014. PMID: 24816234. DOI: 10.3324/ haematol.2014.103820

47 Zuna J, Burjanivova T, Mejstrikova E, Zemanova Z, Muzikova K, Meyer C, Horsley SW, Kearney L, Colman S, Ptoszkova H, Marschalek R, Hrusak O, Stary J, Greaves M and Trka J: Covert preleukemia driven by MLL gene fusion. Genes Chromosomes Cancer 48(1): 98-107, 2009. PMID: 18932267. DOI: 10.1002/gcc. 20622

48 Jonveaux P, Hillion J, Bernard O, Le Coniat M, Derre J, Flexor M, Larsen CJ and Berger R: Distinct MLL gene rearrangements associated with successive acute monocytic and lymphoblastic leukemias in the same patient. Leukemia 8(12): 2224-2227, 1994. PMID: 7808011.

49 Emerenciano M, Meyer C, Mansur MB, Marschalek R, Pombode-Oliveira MS and Brazilian Collaborative Study Group of Infant Acute Leukaemia: The distribution of MLL breakpoints correlates with outcome in infant acute leukaemia. Br J Haematol 161(2): 224-236, 2013. PMID: 23432364. DOI: 10.1111/bjh.12250

50 Meyer C, Lopes BA, Caye-Eude A, Cave H, Arfeuille C, Cuccuini W, Sutton R, Venn NC, Oh SH, Tsaur G, Escherich G, Feuchtinger T, Kosasih HJ, Khaw SL, Ekert PG, Pombo-de-Oliveira MS, Bidet A, Djahanschiri B, Ebersberger I, Zaliova M, Zuna J, Zermanova Z, Juvonen V, Grumayer RP, Fazio G, Cazzaniga G, Larghero P,
Emerenciano M and Marschalek R: Human MLL/KMT2A gene exhibits a second breakpoint cluster region for recurrent MLLUSP2 fusions. Leukemia 33(9): 2306-2340, 2019. PMID: 30899083. DOI: $10.1038 / \mathrm{s} 41375-019-0451-7$

51 Rössler T and Marschalek R: An alternative splice process renders the MLL protein either into a transcriptional activator or repressor. Pharmazie 68(7): 601-607, 2013. PMID: 23923644. DOI: $10.1055 / \mathrm{s}-0033-1343653$

52 Fukuhara S, Chikumi $\mathrm{H}$ and Gutkind JS: Leukemia-associated Rho guanine nucleotide exchange factor (LARG) links heterotrimeric G proteins of the G(12) family to Rho. FEBS Lett 485(2-3): 183-188, 2000. PMID: 11094164. DOI: 10.1016/ s0014-5793(00)02224-9

53 Booden MA, Siderovski DP and Der CJ: Leukemia-associated Rho guanine nucleotide exchange factor promotes $\mathrm{G}$ alpha q-coupled activation of RhoA. Mol Cell Biol 22(12): 4053-4061, 2002. PMID: 12024019 . DOI: $10.1128 / \mathrm{mcb} .22 .12 .4053-4061.2002$

54 Hikumi H, Fukuhara S and Gutkind JS: Regulation of G proteinlinked guanine nucleotide exchange factors for Rho, PDZRhoGEF, and LARG by tyrosine phosphorylation: evidence of a role for focal adhesion kinase. J Biol Chem 277(14): 1246312473, 2002. PMID: 11799111. DOI: 10.1074/jbc.M108504200

55 Swiercz JM, Kuner R, Behrens J and Offermanns S: Plexin-B1 directly interacts with PDZ-RhoGEF/LARG to regulate RhoA and growth cone morphology. Neuron 35(1): 51-63, 2002. PMID: 12123608. DOI: 10.1016/s0896-6273(02)00750-x

56 Dubash AD, Wennerberg K, Garcia-Mata R, Menold MM, Arthur WT and Burridge K: A novel role for Lsc/p115 RhoGEF and LARG in regulating RhoA activity downstream of adhesion to fibronectin. J Cell Sci 120(Pt 22): 3989-3998, 2007. PMID: 17971419. DOI: $10.1242 /$ jcs.003806

57 Kitzing TM, Sahadevan AS, Brandt DT, Knieling H, Hannemann S, Fackler OT, Grosshans J and Grosse R: Positive feedback between Dia1, LARG, and RhoA regulates cell morphology and invasion. Genes Dev 21(12): 1478-1483, 2007. PMID: 17575049. DOI: $10.1101 /$ gad .424807

58 Goulimari P, Knieling H, Engel U and Grosse R: LARG and mDia1 link Galpha12/13 to cell polarity and microtubule dynamics. Mol Biol Cell 19(1): 30-40, 2008. PMID: 17959834. DOI: $10.1091 / \mathrm{mbc} . \mathrm{e} 06-11-1045$

59 Evelyn CR, Ferng T, Rojas RJ, Larsen MJ, Sondek J and Neubig RR: High-throughput screening for small-molecule inhibitors of LARG-stimulated RhoA nucleotide binding via a novel fluorescence polarization assay. J Biomol Screen 14(2): 161-172, 2009. PMID: 19196702. DOI: 10.1177/1087057108328761

60 Shi Y, Zhang J, Mullin M, Dong B, Alberts AS and Siminovitch $\mathrm{KA}$ : The mDial formin is required for neutrophil polarization, migration, and activation of the LARG/RhoA/ROCK signaling axis during chemotaxis. J Immunol 182(6): 3837-3845, 2009. PMID: 19265163. DOI: 10.4049/jimmunol.0803838

61 Martz MK, Grabocka E, Beeharry N, Yen TJ and Wedegaertner PB: Leukemia-associated RhoGEF (LARG) is a novel RhoGEF in cytokinesis and required for the proper completion of abscission. Mol Biol Cell 24(18): 2785-2794, 2013. PMID: 23885121. DOI: $10.1091 / \mathrm{mbc}$.E12-07-0533

62 Guilluy C, Swaminathan V, Garcia-Mata R, O’Brien ET, Superfine R and Burridge K: The Rho GEFs LARG and GEFH1 regulate the mechanical response to force on integrins. Nat Cell Biol 13(6): 722-727, 2011. PMID: 21572419. DOI: $10.1038 /$ ncb2254 
63 Zou S, Teixeira AM, Yin M, Xiang Y, Xavier-Ferrucio J, Zhang PX, Hwa J, Min W and Krause DS: Leukaemia-associated Rho guanine nucleotide exchange factor (LARG) plays an agonist specific role in platelet function through RhoA activation. Thromb Haemost 116(3): 506-516, 2016. PMID: 27345948. DOI: $10.1160 / \mathrm{TH} 15-11-0848$

64 Xie Y, Gao L, Xu C, Chu L, Gao L, Wu R, Liu Y, Liu T, Sun XJ, Ren R, Tang J, Zheng Y, Zhou Y and Shen S: ARHGEF12 regulates erythropoiesis and is involved in erythroid regeneration after chemotherapy in acute lymphoblastic leukemia patients. Haematologica 105(4): 925-936, 2020. PMID: 31467124. DOI: 10.3324/haematol.2018.210286

65 Ong DC, Ho YM, Rudduck C, Chin K, Kuo WL, Lie DK, Chua CL, Tan PH, Eu KW, Seow-Choen F, Wong CY, Hong GS, Gray JW and Lee AS: LARG at chromosome 11q23 has functional characteristics of a tumor suppressor in human breast and colorectal cancer. Oncogene 28(47): 4189-4200, 2009. PMID: 19734946. DOI: $10.1038 /$ onc.2009.266
66 Tate JG, Bamford S, Jubb HC, Sondka Z, Beare DM, Bindal N, Boutselakis H, Cole CG, Creatore C, Dawson E, Fish P, Harsha B, Hathaway C, Jupe SC, Kok CY, Noble K, Ponting L, Ramshaw CC, Rye CE, Speedy HE, Stefancsik R, Thompson SL, Wang S, Ward S, Campbell PJ and Forbes SA: COSMIC: the Catalogue Of Somatic Mutations In Cancer. Nucleic Acids Res 47(D1): D941-D947, 2019. PMID: 30371878. DOI: 10.1093/nar/gky1015
Received September 30, 2020

Revised October 25, 2020

Accepted October 27, 2020 